\title{
As áreas naturais protegidas e a responsabilidade social e ambiental das empresas: o caso do Mosaico da Mata Atlântica Central Fluminense e do Comperj *
}

\section{Protected areas and social and enviromental responsibility of enterprises: the case of the Mosaico da Mata Atlântica Central Fluminense and the Comperj (Petrochimical complex of Rio de Janeiro)}

\author{
Gian Mario GIULIANI**
}

\begin{abstract}
RESUMO
Queremos refletir sobre as tensões que as Unidades de Conservarão (UCs) enfrentam para sustentar sua política de conservação em um o território que acaba sendo escolhido para a implantação de um grandes complexo industrial. Referimos-nos à construção do Complexo Petroquímico do Rio de Janeiro (Comperj) da Petrobras, a ser localizado muito próximo do Mosaico da Mata Atlântica Central Fluminense (MMACF) e, mais particularmente, da Área de Proteção Ambiental (Apa) de Guapimirím. Apesar dos Conselhos Gestores das respectivas áreas, prevendo impactos ambientais e sociais muito fortes, ter se manifestado contrários à localização escolhida pela empresa, procedeu-se ao licenciamento prévio dessa grande obra. Buscamos mostrar como o lema da responsabilidade social e ambiental da empresa que responde pelo projeto não se realizam na prevenção e na precaução, no sentido de planejar as intervenções no sentido de evitar os problemas previstos. A responsabilidade social e ambiental funda-se em atitudes que priorizam os interesses da empresa, tornando-a disponível somente para limitar os problemas previstos e compensar ou reparar os danos causados.
\end{abstract}

Palavras-chave: responsabilidade ambiental; áreas protegidas; políticas de conservação.

\footnotetext{
* Trabalho apresentado no VI WORKSHOP EMPRESA, EMPRESÁRIOS E SOCIEDADE 2008, Universidade Federal Fluminense (UFF), Niterói, Brasil, 7, 8 e 9 de abril de 2008.

** Professor do Programa de Pós-graduação em Sociologia e Antropologia - PPGSA - da Universidade Federal do Rio de Janeiro - UFRJ. Membro do Conselho Gestor da Apa de Guapimirím e do Mosaico da Mata Atlântica Central Fluminense.
} 


\begin{abstract}
The article thinks about the pressures that defy the "protected areas" in order to sustain their politics of conservation in the case that the territory had been chose for setting an enormous industrial complex. We refer to the construction of the Complexo Petroquímico do Rio de Janeiro (Comperj) by the Petrobras Company at a very short distance from the Mosaico da Mata Atlântica Central Fluminense - MMACF (a whole of 22 protected areas) and, particularly, from the Apa de Guapimirim,that is the last original haven of the mangrove system of the Guanabara Bay. It is reasonable to preview that the protected areas will suffer strong environmental and social impacts. We wont to make evident that the social and environmental responsibility flaunted by Petrobras is not preventive, in the sense of planning the actions anticipating their consequences and conceiving its project in order to avoid risks. Its social and environmental responsibility bases on attitudes that only aim at the containment of the principal predicted problems and at the compensation for the caused damages.
\end{abstract}

Key words: environmental responsibility; protected areas; conservation politics.

\section{Introdução}

A oposição entre conservação da natureza e crescimento econômico estaria superada em termos teóricos através de alguns conceitos formulados nas últimas duas décadas, sobretudo o de "desenvolvimento sustentável" e de "responsabilidade social e ambiental das empresas" (RSAE). Entretanto, consideramos que a oposição persiste na prática e no pensamento empresarial (mesmo nas empresas que se auto-definem líderes na RSAE), assim como nas próprias políticas públicas para o crescimento econômico.

Na perspectiva do crescimento, conservar a natureza significa não aproveitar plenamente dos recursos produtivos que esta oferece e desperdiçar oportunidades em um contexto fortemente competitivo. Diferentemente, os que defendem a conservação consideram que a busca frenética do crescimento e a insaciável espiral produção-consumo pressionam os sistemas da natureza e ameaçam, a curto prazo, a existência de grupos sociais que vivem diretamente dos recursos naturais e, a longo prazo, a própria reprodução da espécie humana. No cerne das argumentações conservacionistas está a convicção de que a sobrevivência dos seres humanos depende de sua capacidade de conhe- cer e de adaptar-se às leis da natureza, mantendo o respeito das diversas formas de reprodução da mesma, assim que as atividades humanas possam se sustentar no tempo. Para os eco-ambientalistas é central a idéia de desenvolvimento humano e social, no sentido de uma positiva expansão das potencialidades humanas, integrada com o meio ambiente e a natureza. Segundo essa perspectiva, os elementos da natureza, antes de serem recursos avaliados economicamente, são bens materiais e imateriais fundamentais para a qualidade da vida humana.

A constituição da maioria das Unidades de Conservação (UCs) busca responder a algumas das demandas ecoambientalistas, especialmente as UCs de "usos sustentável”, isto é, as que incluem a presença de diversos grupos sociais e particularmente das chamadas "populações tradicionais". " Mesmo sendo esta uma definição que força o enquadramento de grupos com características sociais e culturais bastante diferentes, permite estabelecer a identificação de uma parte da população que, no interior da sociedade atual, organiza sua reprodução à margem do sistema capitalista moderno e desenvolve atividades ligadas ao seu específico território e às peculiares configurações ecossistêmicas do mesmo. A lógica que orienta a constituição de uma UC geralmente responde à necessidade de “de-

1 A designação de "população tradicional” apareceu na década de 1980 para identificar certas populações que até então eram denominadas de "nativas”. Estas têm sistemas de produção baseados no trabalho familiar e usam tecnologia de muito baixo impacto ambiental em atividades nas quais a natureza tem um peso determinante, como o extrativismo, a agricultura de auto-consumo, a pesca artesanal, a captura de caranguejos. Ver: < www.ibama.gov.br/resex/pop.htm.> 
fender” uma determinada área da expansão de atividades humanas que ameaça a integridade de seu ecossistema considerado relevante. Portanto, a reflexão sobre a problemática ambiental a partir das áreas naturais protegidas permite compreender com maior clareza dimensões problemáticas da relação entre o crescimento econômico, o desenvolvimento social e a conservação da natureza.

Queremos aqui refletir sobre as tensões que as UCs enfrentam para sustentar sua política de conservação, quan- do o seu território do entorno acaba sendo escolhido como mais apropriado para a implantação de um grande complexo industrial. Referimos-nos ao projeto de construção pela Petrobras do Complexo Petroquímico do Rio de Janeiro (Comperj), em uma localidade muito próxima do Mosaico da Mata Atlântica Central Fluminense ${ }^{2}$ e, mais particularmente, da Área de Proteção Ambiental (Apa) de Guapimirím, uma das suas UCs.

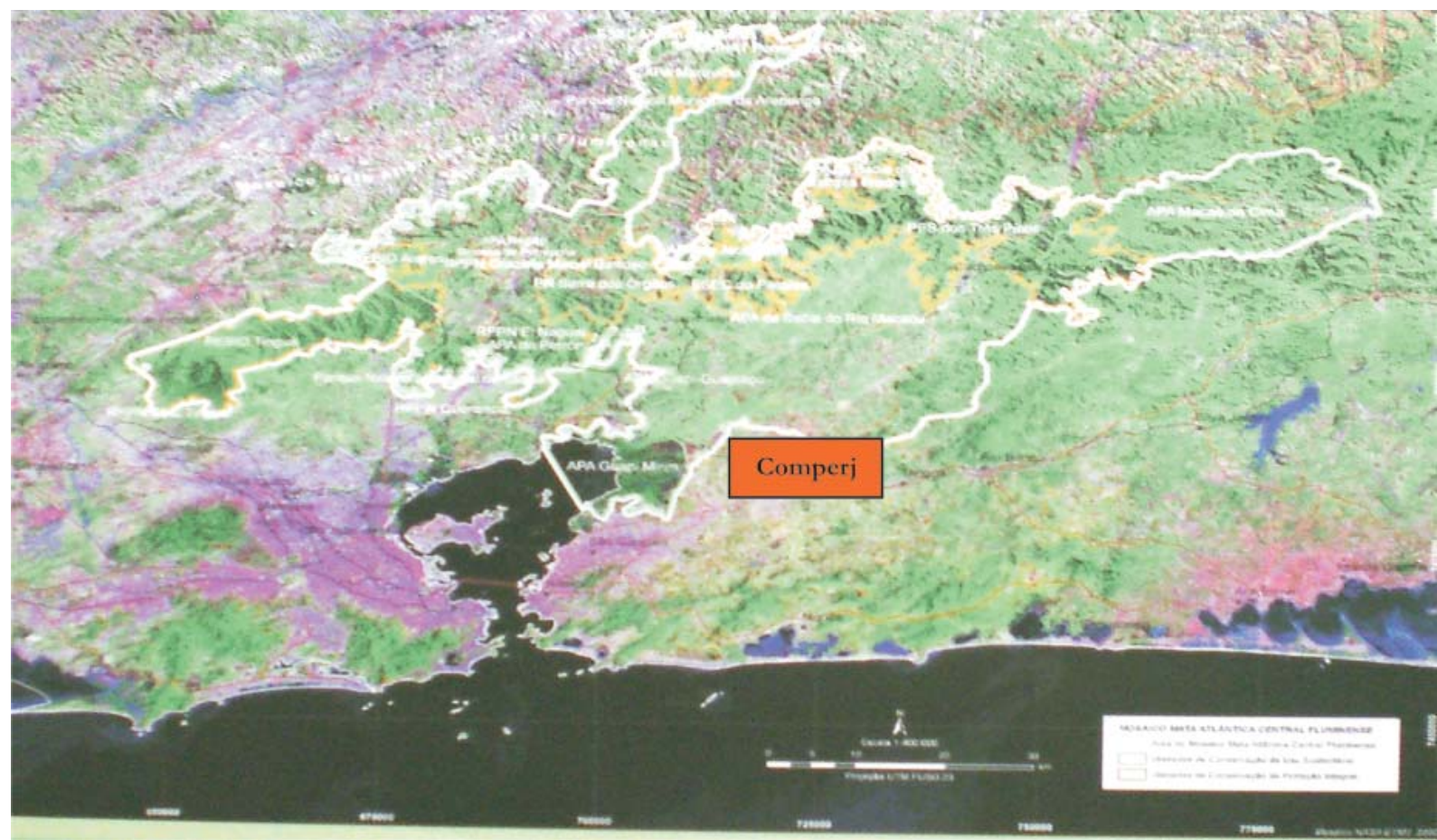

LOCALIZAÇÃO DO COMPERJ RELATIVAMENTE AO CONTORNO DO MMACF E DA APA DE GUAPIMIRÍM NO INTERIOR DO CONTORNO

2 O MMACF foi criado pela Portaria do Ministério do Meio Ambiente em dezembro de 2006 e reúne 22 Unidades de Conservação: 2 Reservas Biológicas, 3 Estações Ecológicas, 1 Monumento Natural, 4 Parques, 8 Áreas de Proteção Ambiental, 4 Reservas Particulares do Patrimônio Natural. Destas UCs, 5 são Federais, 7 Estaduais, 6 Municipais e 4 Privadas. Ocupando uma área de 233.710 hectares em 13 municípios. 
Da realização deste projeto, é possível prever que as áreas protegidas em questão sofrerão fortes impactos ambientais e sociais negativos.

\section{A sociedade e o ambiente}

No fundo da oposição entre a sociedade e a natureza encontramos sempre questões sociais não resolvidas, assim como no fundo das idéias de "conservar" a natureza não há somente a manutenção dos elementos da natureza e a garantia do funcionamento de seus ecossistemas. Conservar os recursos naturais significa concebê-los como elementos possuidores de identidade específica e como parte do sistema complexo sociedade-natureza. A conservação, portanto, impõe uma reconversão de valores nas próprias relações sociais. Ao lado do reconhecimento do valor da biodiversidade está a valorização da "sociodiversidade", isto é, a apreciação dos modos de vida mais simples, diferentes do predominante moderno-urbano e tecno-dependente.

As políticas de proteção das áreas naturais ecologicamente significativas são compreensíveis face às agressões inspiradas no desejo de enriquecimento de fazendeiros, garimpeiros, madeireiros, pescadores, caçadores, empresas imobiliárias e de turismo. Tal desejo muitas vezes leva a práticas desordenadas e predatórias que penetram irregularmente nos confins das UCs e ameaçam seja os sistemas naturais, seja os sistemas sociais economicamente marginais e de baixo impacto ambiental que a estes são ligados. Tais agressões são decorrências perversas da supremacia cultural exercida pelo socialmente legitimo "desejo de riqueza" sobre os valores da conservação, tornando-se dimensões problemáticas das relações entre o crescimento econômico, o desenvolvimento social e a conservação. Entretanto, não é sobre estas ameaças que queremos aqui refletir, já que a própria existência da UCs torna estas atividades ilegais, codificando-as como "crimes ambientais". Nos parece mais interessante refletir sobre como os limites de uma UC, marcando a distinção entre o que é possível fazer dentro das áreas protegidas e o que pode-se fazer fora destas, alimentam uma perspectiva de oposição entre a "conservação da natureza” ao "crescimento econômico".

Não podemos esquecer que há um intercambio continuo entre UCs e o ambiente de seu entorno. As UCs não são indiferentes ao que acontece fora de seus limites, an- tes, o seu entorno é o ambiente fundamental para a sua própria vida, já que recebem deste informações e meios de vida utilizados para a própria auto-regulação. Este intercambio é uma via de mão dupla. A sociedade que está de fora dos limites recebe informações e meios de vida que contribuem significativamente no plano cultural, jurídico e prático, para a regulação das relações sociedade-natureza no nível local e até geral.

As políticas que instituem as UCs deveriam pressupor que haja um intercâmbio destas com o ambiente que as inclui, de maneira a contribuir para o seu próprio desenvolvimento, como para o desenvolvimento do território maior. Em outras palavras, as características especificas das UCs devem se tornar partes importantes e elementos propulsores do desenvolvimento da região na qual se inserem. Consequentemente, se houver uma proposta de intervenção econômica em uma determinada região, esta deve combinar-se com as Unidades de Conservação presentes. Entretanto, dependendo do contexto, ou dos compromissos assumidos no plano global, os diversos impulsos políticoeconômicos levam a subordinar a política de conservação aos interesses das empresas e dos grandes projetos estatais, produzindo situações que dificultam uma apropriada proteção das áreas naturais. Como estas iniciativas não podem mais ser empreendidas simplesmente por decreto, não só necessitam de seguir procedimentos definidos por lei, mas também devem fornecer justificações morais em termos de bem comum (BOLTANSKI; CHIAPELLO, 1999). Para isso, os argumentos mais utilizado recorrem à necessidade de modernização, de criação de emprego e de progresso, apoiados por intensas campanhas de propaganda que retrata as empresas como paladinos da "responsabilidade social e ambiental”.

\section{A responsabilidade social e a responsabilidade ambiental das empresas - RSAE}

Nos últimos anos, a Responsabilidade Social das Empresas (RSE) apresenta-se, no discurso empresarial, naturalmente associada à Responsabilidade Ambiental (RAE), transmitindo assim a imagem de que o mundo empresarial compreendeu a recente renovação dos anseios da sociedade. O Meio Ambiente é hoje reconhecido como sendo a "dimensão mais geral" e englobante da vida social. Com efeito, ao passo que as ações sociais sempre se dirigem a grupos sociais identificados, a degradação do meio 
ambiente e dos recursos naturais acaba afetando, em maior ou menor medida, todo o mundo. Logo, nenhuma empresa poderia se apresentar como socialmente responsável se não fosse ambientalmente responsável. Seus programas e ações sociais perderiam toda credibilidade se suas atividades produtivas poluíssem o ar, as águas, o solo ou devastassem as áreas verdes e as florestas. Por outro lado, uma empresa poderia não ter nenhuma iniciativa que a qualifique como socialmente responsável, mas ter programas e práticas ambientais corretas e responsáveis, o que lhes permitiria de apresentar-se à sociedade com um "surplus" que a distingue favoravelmente das outras empresas. Por quê? Porque a Responsabilidade Social e a Responsabilidade Ambiental têm corrido em trilhos diferentes.

A RSE, como iniciativa das empresas para "ajudar" grupos sociais carentes é antiga quanto a própria instituição empresas. Às diversas formas de filantropia discreta, mantida predominantemente na esfera do privado, se somam aos programas de ação com clara visibilidade pública associada à imagem da empresa. ${ }^{3}$ Característica comum a esses programas é obstinada relutância a interagir com a esfera pública ou a dialogar com as principais demandas provenientes da sociedade. A RSE se mantém firme na sua dimensão de "iniciativa privada" das empresas. ${ }^{4}$

A preocupação com a questão ambiental tem crescido rapidamente em diferentes setores da sociedade, inclusive no mundo empresarial. Pelo que se refere ao Brasil, cabe a esse respeito relembrar importantes eventos. Nos anos de 1980, as pressões do ativismo ambientalista influenciaram o espírito da nova Constituição e levaram ao empresariado as preocupações com o meio ambiente, até então absolutamente inexistentes neste segmento social. A conferência mundial promovida pelas Nações Unidas no Rio de Janeiro em 1992, abriu o caminho para a legitimação de convenções para regular uma série de relações no comércio internacional (certificações, códigos de conduta, protocolos internacionais, etc.) que orientavam as empresas para novos padrões de comportamento ambiental. Algumas grandes empresas nacionais e multinacionais con- tribuíram na formação de novas regras, às vezes se adiantando às próprias leis e difundindo a idéia de que a preocupação das empresas com o meio ambiente é um fenômeno crescente e irreversível porque é também rentável. ${ }^{5}$ Essas atitudes aparecem definidas como "proativas" porque são apresentadas como surgindo de iniciativa espontâneas das empresas.

Se analisarmos mais detidamente as atitudes e iniciativas de Responsabilidade Social e de Responsabilidade Ambiental das empresas, podemos ver que sua simbiose é apenas construída, havendo substantivas diferenças entre elas. A primeira se firma em práticas tradicionalmente voluntárias pelas quais seja empresários individuais, seja empresas, se dedicam às mais diversas formas de solidariedade social e filantrópica, como doações, assistência social, voluntariado, promoção de programas locais, etc. A RSE ganha força, como uma palavra de ordem absolutamente nova e moralmente imperiosa, ${ }^{6}$ sobretudo a partir da segunda metade dos anos de 1990, tornando-se mais insistente quando é mais forte a desregulação do mercado de trabalho e mais enfraquecidos os direitos trabalhistas (GALLINO, 2005). Diversamente, a RAE, embora ainda frágil, tem crescido pressionada pela sociedade e por um processo de regulação que se aperfeiçoa no âmbito nacional e nos acordos internacionais. O caráter proativo das iniciativas empresariais nesse âmbito deve ser entendido, sobretudo, em dois sentidos. De um lado, se adiantar à leis que "fatalmente" irão condenar certas práticas correntes, evitando assim punições onerosas; de outro, seguindo a mesma lógica da modernização e das inovações tecnológicas, buscar uma colocação vantajosa na competição do mercado. É comum, nesse sentido, ouvir os empresários dizer que o meio ambiente é o espaço que oferece grandes oportunidades de novos negócios (ALMEIDA, 2002).

As diferentes origens que distingue a Responsabilidade Social da Responsabilidade Ambiental levam a uma diferença qualitativa importante. A RSE representa nas relações sociais a "reafirmação" e o "fortalecimento" do di-

\footnotetext{
3 A filantropia não é uma prática exclusiva do mundo empresarial, já que aproximadamente 70\% da população adulta faz doações de objetos, dinheiro ou bens a instituições ou a pessoas necessitadas (ANDERSON, 2000). Estudos recentes discutem a Filantropia Empresarial, ver entre outros: Landim (1998); Landim e Scalon (2000); Marinho (2003).

4 Cappellin e Giuliani (2004).

5 A este respeito pode-se ver, entre outros: Anderson e Leal (1992); Kinlaw (1997); Hawken (1999); Almeida (2002).

6 Ver a propaganda do Instituto Etos de São Paulo, que depois de ilustrar um caso de ação social corporativa, pergunta: “Você já fez a sua parte?”.
} 
reito de propriedade nos sujeitos das empresas e no grupo social dos empresários. Com efeito, é graças ao fato de serem proprietários de suas empresas e de seu patrimônio que os empresários podem decidir de fomentar programas e ações sociais e é graças ao direito de propriedade que estas ações "têm que ser”, e "só podem ser”, voluntárias e discricionárias. A RAE, ao contrário, se coloca como um "limite" ao direito de propriedade. Com efeito, a legislação ambiental e os acordos internacionais estabelecem regras de conduta que reduzem a discricionariedade das empresas nas formas de produzir e nas formas de se utilizar de recursos naturais de sua propriedade.

Finalmente, as duas formas de Responsabilidade, embora ambas possam refluir em contextos de crise econômica (estagnação, recessão), ou se expandir em períodos de crescimento, reagem a essas dinâmicas segundo mecanismos muito diferentes. Com efeito, é razoável pensar que, em períodos de crise econômica tanto as práticas sociais das empresas, como o engajamento ambiental das mesmas possam ser reduzidos ou interrompidos. Entretanto, ao passo que um processo de regressão da RSE dependeria exclusivamente das decisões empresariais, para a regressão da RAE seria necessária uma considerável mobilização política e um empenho das esferas executiva, legislativa e judiciária. A heterogeneidade econômica e cultural do empresariado possibilita que grupos específicos pressionem para tornar a legislação ambiental mais flexível em nome do pretenso desenvolvimento econômico, ${ }^{7}$ ou atribuam o desempenho da economia abaixo de suas possibilidades às limitações impostas pela legislação ambiental. Entretanto, sendo a RAE regulada por leis e por acordos internacionais, somente importantes mudanças no nível de governo podem por freios à legislação, ou restringir a adesão do país aos acordos de cooperação considerados desvantajosos para a economia e o crescimento.

Desta forma, tanto a RSE como a REA, são uma questão essencialmente política que influencia a hierarquia das formas institucionais. Segundo Bodet e Lamarche (2007), tais lemas expressariam campos de força, nos quais o cres- cente poder das empresas transnacionais impõe um confronto nos processos de institucionalização. As regras produzidas pelas empresas (programas sociais, cartas de princípios, códigos de conduta, projetos ambientais) podem ser consideradas como soft law, por serem regras não impostas, mas voluntárias. O temor dos autores é, como eles próprios dizem, que: “[...] le discours sur la soft law peut avoir comme effet de légitimer la primauté de la soft law sur la loi contraignante".

Talvez, seja nesse sentido que teríamos que interpretar a insistência das empresas em manter unidas as duas formas de responsabilidade. Vale dizer, a lógica que orienta a responsabilidade social das grandes empresas, como reforço para as justificações do crescimento em termos de "progresso" e "modernização", engloba dentro de si a responsabilidade ambiental, a submete aos interesses corporativos e a usa para empalmar leis e normas coletivas em campo ambiental.

\section{Empresas e meio ambiente no estado do Rio de Janeiro}

As indústrias do Sul e do Sudeste são as que produzem resíduos perigosos em maior quantidade. Nos dados de 2002, segundo Ricardo Rose, Diretor de Meio Ambiente da Câmara de Comércio e Indústria Brasil-Alemanha, seriam 2,7 milhões de toneladas (ROSE, 2008). Do total dos resíduos industriais perigosos, segundo o Diretor, cerca de $20 \%$ é disposta corretamente em aterros sanitários de classe I, ou são incinerados. Outra parte estaria estocada nas próprias empresas geradoras, aguardando uma destinação final (que pode demorar anos). Outra ainda simplesmente desaparece, sem que os órgãos de controle ambiental tenham qualquer informação. ${ }^{8}$

A região da Baía de Guanabara é considerado o segundo maior parque industrial do Brasil, com cerca de 14 mil indústrias. Segundo Wambier (2004), das centenas de empresas que estão instaladas no entorno da baía, quinze

7 Como fazem, por exemplo, os produtores rurais que pedem a isenção da licença ambiental para suas atividades e reivindicam, através de seus representantes no Congresso Nacional, a redução das dimensões das áreas de florestas que devem ser preservadas.

8 Rose sustenta que:

São poucos os municípios no Brasil que dispõe de um aterro sanitário, construído segundo normas técnicas recomendadas pelas agencias ambientais. A maioria dos 5.568 municípios brasileiros utiliza-se de buracos cavados no solo, “lixões”, sem qualquer tipo de isolamento, onde os resíduos municipais são jogados. Em muitas cidades, para agravar a situação, juntam-se aos resíduos domésticos os resíduos hospitalares e até os industriais - perigosa convivência, tolerada ou ignorada pelo poder municipal. A reciclagem é praticada em aproximadamente 400 municípios brasileiros. 
delas foram consideradas pela Fundação Estadual de Engenharia de Meio Ambiente (Feema) do nível mais alto no grau de perigo, por armazenarem grandes quantidades de produtos químicos tóxicos e inflamáveis e por serem potenciais causadoras de acidentes ambientais muito graves, como explosões, vazamentos de gases ou de produtos quí- micos altamente tóxicos.

\section{As principais empresas do entorno da Baía da Guanabara}

\section{Conheça as empresas}

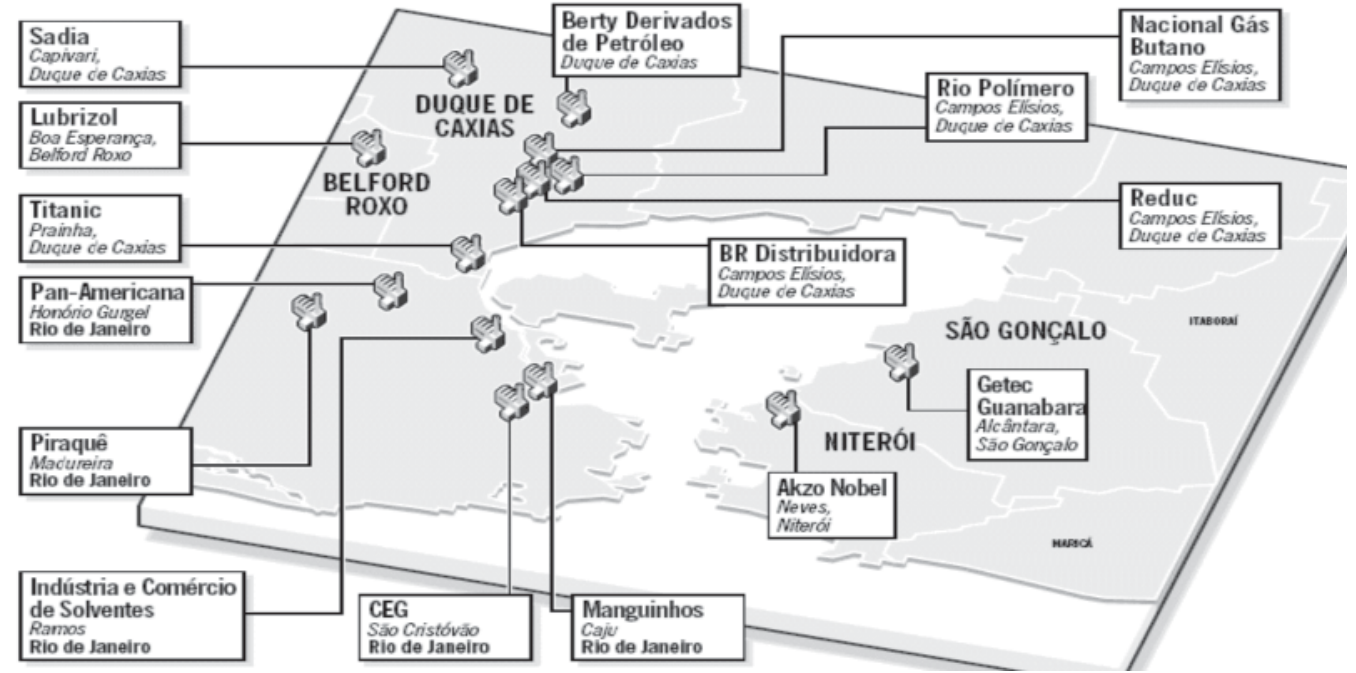

MAPA DAS PRINCIPAIS EMPRESAS NA REGIÃO DA GUANABARA FONTE: O Globo, 22 de setembro de 2004.

Todas as empresas afirmam possuir planos de escape e de contingência em caso de acidentes, entretanto, há casos de comunidades com residenciais localizadas a apenas 20 metros d distância do perímetro das indústrias. ${ }^{9}$

A pesquisa Mapa dos Conflitos Ambientais do estado do Rio de Janeiro-1992-2002, ${ }^{10}$ mostra que $72 \%$ dos 251 conflitos ambientais em áreas pobres de 49 municípios do Rio, registrados entre 1992 e 2002, são relacionados a atividades industriais: disposição inadequada e lançamento clandestino de resíduos tóxicos, poluição do solo, do ar e da água, atividades de prospecção de petróleo, atividade mineradora e ao vazamento de óleo. Interessante ressaltar que os danos causados ao meio ambiente seguem o ritmo do crescimento econômico. Como observa Junqueira (2001):11 "Quando há expansão de capacidade produtiva, os impactos ambientais são evidentes, pois não há tecnologia disponível que aproveite $100 \%$ dos insumos”. Para a autora, mesmo quando as atividades propostas se põem o objetivo de reduzir a pobreza, poderá ser justamente a população mais pobre a que irá sofrer as piores conseqüências, devido ao seguinte círculo vicioso: as áreas poluídas ficam desvalorizadas, incentivando sua ocupa-

9 Como é o caso da Piraquê, da Titanic e da Refinaria de Manguinhos (WAMBIER, 2004).

10 Estudo coordenado pelo Prof. Henri Acselrad, do Instituto de Pesquisa e Planejamento Urbano e Regional (IPPUR-UFRJ) e por Jean Pierre Leroy da Fundação dos Órgãos para Assistência Social e Educacional (FASE), disponível em CD.

11 Professora do Instituto de Economia da Universidade Federal do Rio de Janeiro. 
ção pela população de baixa renda e os locais onde vivem essas populações podem ser mais facilmente poluídos, pois elas não apresentam força política nem organização suficientes para evitar tais problemas ambientais (ACSELRAD, 2004).

Nogueira e Torres (2008) observam que nos últimos 17 meses, a Secretaria do Ambiente do Rio licenciou em tempo recorde obras, entre as quais algumas de interesse direto do Governo Federal e de grande impacto ambiental. A Secretaria informa que foram emitidas 2.068 licenças desde fevereiro de 2007 até maio de 2008, correspondente à quantidade emitida nos três anos anteriores de 2004 a 2006. Os autores comentam que a maior agilidade na emissão de licenças deve-se, não somente a uma nova metodologia de análise, mas também ao apoio financeiro da Federação das Indústrias do Estado do Rio de Janeiro (Firjan), a qual, através de um convenio assinado em fevereiro de 2007, disponibilizou 22 milhões de reais para que a Secretaria pudesse contratar 147 técnicos temporários atuando em apoio à emissão de licenças, assim como contratar funcionários temporários, realizar estudos de gestão, comprar carros e computadores.

As maiores e mais impactantes obras, cujo licenciamento prévio foi dado pela FEEMA, têm sido o Arco Metropolitano (rodovia de 146 km entre os municípios de Itaguaí, ao Oeste da Baia da Guanabara e Itaboraí ao Leste) e o Complexo Petroquímico do Rio de Janeiro (Comperj) a ser construído no município de Itaboraí. Para as duas grandes obras a licença da Secretaria do Ambiente veio rapidamente, mesmo que o trajeto da estrada cruze a Floresta Nacional Mário Xavier ${ }^{12}$ e que o Comperj será instalado muito próximo das principais Unidades de Conservação do Estado. Segundo a Secretaria de Meio Ambiente do Estado estes empreendimentos não irão produzir nenhuma perturbação ambiental para a população da região. Entretanto, uma serie de entidades da sociedade civil discordam desta posição. Por exemplo, a presidente da associação civil sem fins lucrativos, Instituto Baía de Guanabara, engenheira química Dora Negreiros, expressou medo pela desordem urbana que poderá ocorrer na região. ${ }^{13}$ Também, o Conselho Gestor do Mosaico da Mata Atlântica Central Fluminense, em duas reuniões ordinárias (em 01-10-07 e 17-03-08), posicionou-se contrário à instalação do complexo petroquímico na localidade decidida pela Petrobras e o Governo Federal e, no mesmo sentido, o Conselho Gestor da Apa de Guapimirím, em reunião ordinária (em dezembro de 2006) já havia expresso uma igual posição.

\section{O Comperj e as unidades de conservação}

O Comperj será o maior empreendimento individual da história da Petrobrás, resultado de um investimento estimado em 15 bilhões de reais está previsto para entrar em operação em 2012. O seu principal objetivo será refinar 150 mil barris diários de petróleo pesado proveniente da Bacia de Campos (Marlim). Este complexo tem uma importância estratégica de enorme relevância e é uma das partes importantes do Programa de Crescimento Acelerado - PAC - lançado no inicio de 2006 pelo Governo Federal. Com efeito, o refino deste específico tipo de petróleo é destinado à produção de pastilhas para a fabricação de objetos de plástico, processo que hoje feito no exterior. Atualmente o petróleo pesado é exportado e são importadas as pastilhas para a produção de plástico. O funcionamento do Comperj deverá gerar para o país uma economia de divisas superior a R\$ 4 bilhões por ano, em decorrência da redução da importação de fontes de matéria-prima petroquímica e da redução da exportação de petróleo pesado. No Comperj, o petróleo passará por duas etapas de produção: na primeira, chegará da Bacia de Campos por dutos e será transformado em produtos petroquímicos básicos; na segunda, estes produtos virarão pastilhas de resina plástica. Em uma terceira etapa, fora do Comperj, estas resinas plásticas serão transformadas por outras indústrias em bens de consumo, como portas de geladeira, peças de carro e objetos vários (Rima-Comperj).

Decidida sua localização no Estado do Rio, trata-

12 Segundo a Lei do Sistema Nacional de Unidade de Conservação da Natureza - SNUC, N. 9.985-2000, a Floresta Nacional é uma Unidade de Conservação de uso sustentável, que admite a exploração sustentável de seus recursos, a permanência de populações tradicionais, a visitação publica, e atividades de pesquisa. A floresta em questão, localizada no município de Seropédica (Baixada Fluminense), foi legalmente criada pelo Decreto Federal n 93.369, de 08/10/86. Sob administração do IBAMA, ocupa uma área de aproximadamente 493 hectares, abrangendo um dos últimos fragmentos florestais da baixada do rio Guandú. Estima-se que atualmente o município de Seropédica conta com menos de 5\% da sua área com cobertura florestal (CORREA; FERNANDES, 1998).

13 Id. 
va-se de definir qual região seria a mais propícia. O impacto social e ambiental seria em qualquer local muito forte. Não somente haveria necessidade de uma área de cerca de 4,5 milhões de $\mathrm{m}^{2}$ e da disponibilidade de 1.200 litros de água por segundo, mas abriria a possibilidade de $200 \mathrm{mil}$ postos de trabalho, entre diretos, indiretos e por efeito renda. Segundo estudos da Fundação Getúlio Vargas, mais de 700 empresas da indústria de transformação poderão se instalar na região até 2015, para produzir plásticos a partir dos produtos do Comperj (RIMA-COMPERJ, p. 8). Entre as várias localizações possíveis, as mais favoráveis pareciam ser as seguintes: Itaguaí, Campos dos Goytacazes e Itaboraí. A primeira foi descartada, devido à bacia aérea já saturada pelas emissões das empresas instaladas naquela região. O Norte Fluminense poderia ter apresentado, para a empresa, a vantagem da proximidade aos campos de produção de petróleo. Entretanto, comportava desvantagens consideradas de grande relevância para os planos do Governo e para a própria empresa. De um lado, o Comperj produziria impactos negativos sobre os melhores cultivos de cana-de-açúcar, o que contrastaria com o plano de extensão e reativação do álcool-etanol na região, Do outro, haveria custos logísticos muito altos, devido à necessidade da implantação de um terminal portuário e à distância em relação aos grandes centros consumidores (RIMACOMPERJ, p. 37). Dessa forma, a escolha mais rentável seria o município de Itaboraí.

Do ponto de vista empresarial as razões desta escolha são as mais "racionais". Como mostra o mapa abaixo, a localização naquela área colocará o Comperj em posição logística muito favorável: disponibilidade de terrenos baratos, proximidade dos maiores centros urbanos, de terminais portuários, de aeroportos, de refinarias e pólos gásquímicos, disponibilidade de uma vasta malha rodoviária e, sobretudo, imediato acesso ao futuro Arco Rodoviário do Rio de Janeiro, ${ }^{14}$ rodovia de extrema importância para o Comperj. ${ }^{15}$

Particularmente preocupante é a localização do gran-

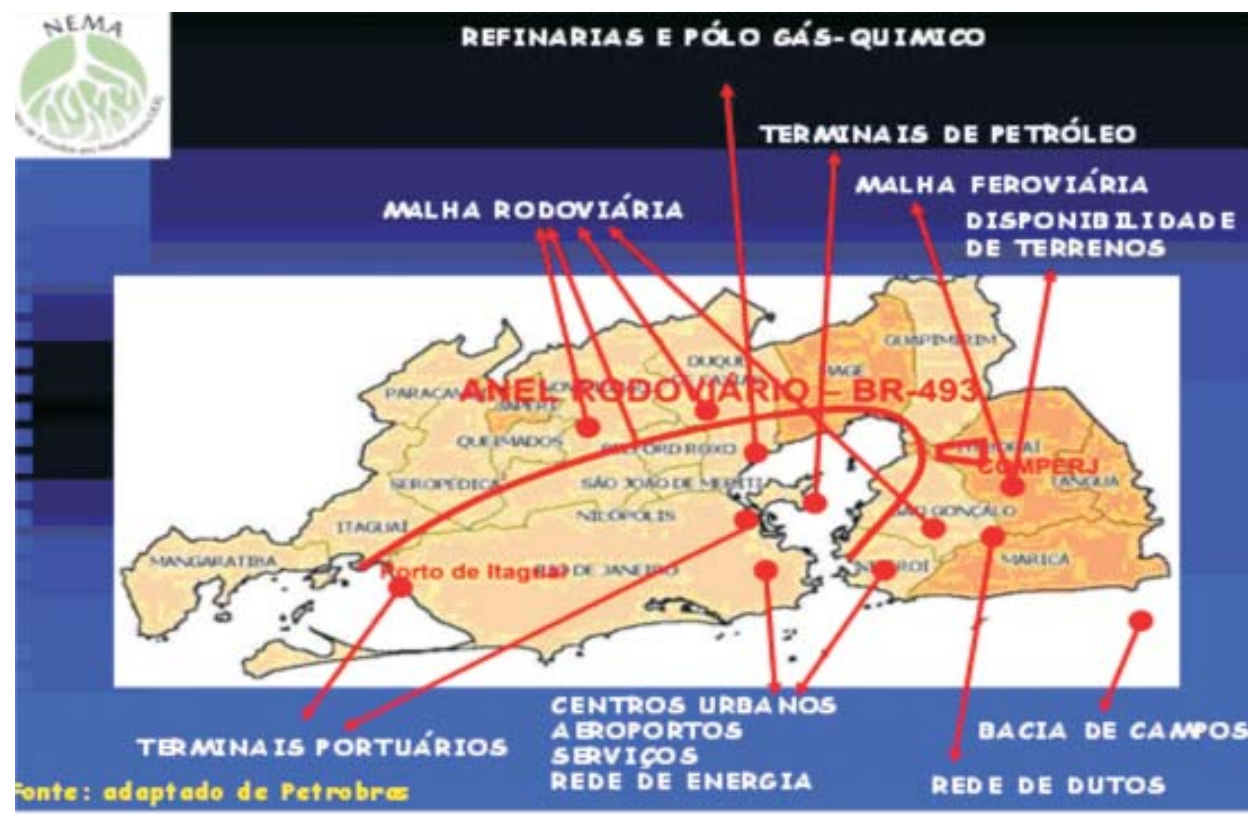

MAPA EXTRAÍDO DA APRESENTAÇÃO DE SOARES (2007) ${ }^{16}$

14 A nova rodovia irà connectar o Porto de Sepetiba ao município de Itaboraí, passando pelos municípios de Seropédica, Nova Iguaçu, Duque de Caxias, Magé e Guapimirím.

15 Segundo Paes Ferreira et al., foi calculado que é mais conveniente (o custo é menor) transportar (seja por dutos ou por navio) o óleo cru extraído em campos offshore para os parques de refino, do que enviar os derivados das refinarias até os principais mercados consumidores, principalmente quando realizados por caminhões tanques.

16 Mário Luiz Gomes Soares é Professor do Núcleo de Estudos em Manguezais - NEMA, da Faculdade de Oceanografia da UERJ, professor do Programa de PósGraduação em Meio Ambiente da UERJ e membro do Conselheiro Gestor da Apa de Guapimirím e do Mosaico da mata Atlântica Central Fluminense. 
de complexo com relação à Apa de Guapimirím. Localizada no recôncavo da Baía de Guanabara, a Ápa é a maior extensão de manguezais do Estado do Rio de Janeiro e abrange os municípios de Magé, Guapimirim, Itaboraí e São Gonçalo, com uma área total de 138,25km².

Criada em 1984, foi a primeira unidade de conserva-

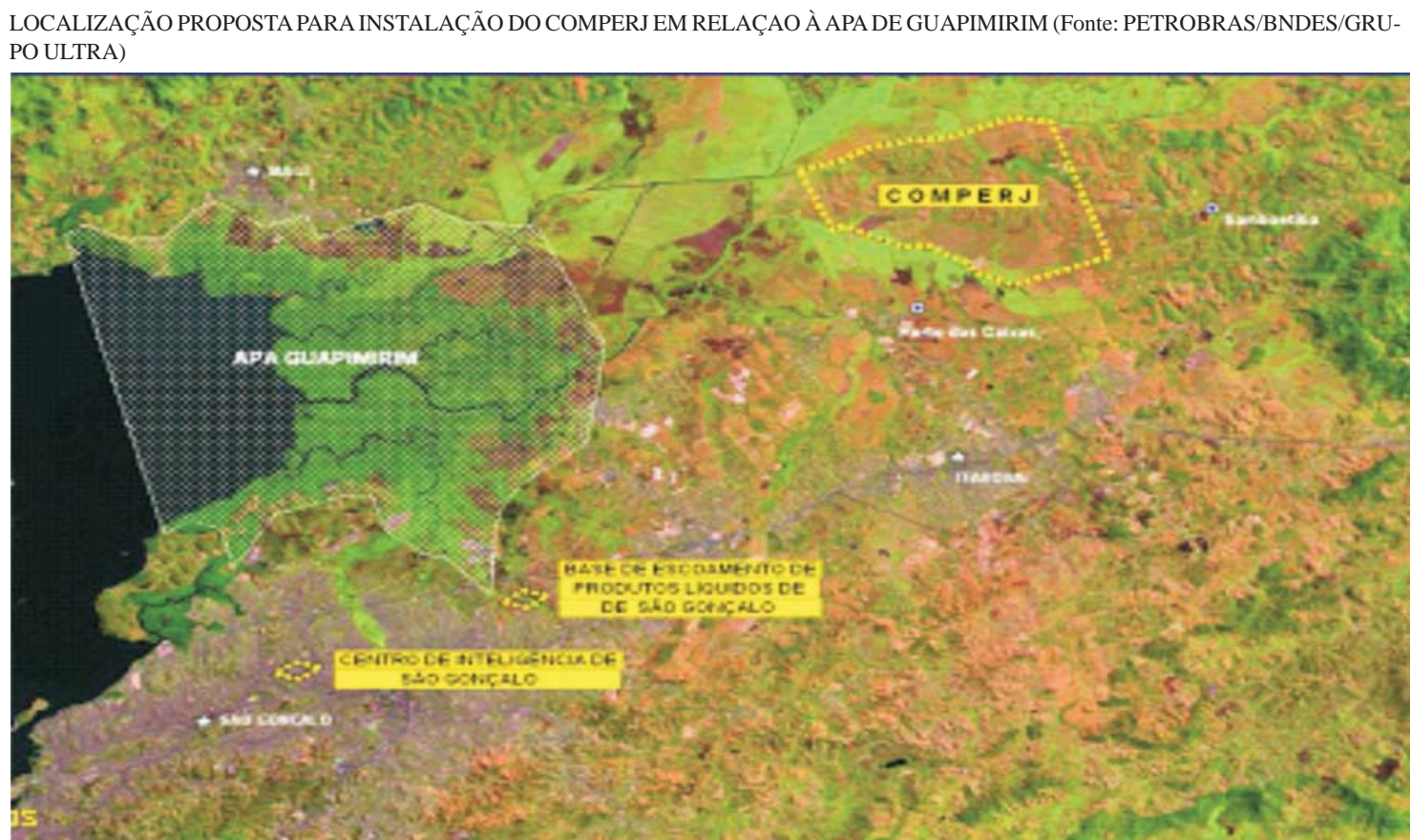

MAPA EXTRAÍDO DA APRESENTAÇÃO DE SOARES (2007)

ção de manguezal do Brasil. Segundo o geógrafo Elmo Amador, a APA de Guapimirim foi resultado de uma disputa entre duas concepções de ocupação da área. "De um lado o todo poderoso DNOS (Departamento Nacional de Obras e Saneamento) que visava a drenagem da região com a erradicação 'dos pestilentos mangues' para produção de terrenos e de outro uma visão ambientalista de defesa dos manguezais e de sua importantes funções." 17

A região de manguezais protegida na APA recobre os aluviões dos principais rios que desembocam na baía cerca de 70\% das contribuições de água fluvial. Segundo o Plano de manejo da APA Guapimirím, aprovado pelo MMA em 2001, esta protege os derradeiros manguezais do recôncavo, viabiliza a sua recuperação como ecossistema e garante ainda a vida na Baía de Guanabara, representada pela cadeia biológica constituída por microorganismos, crustáceos, moluscos, camarões, peixes e mamíferos. Assegura, também, a permanência e a sobrevivência de uma população humana (sobretudo pescadores e caranguejeiros), vivendo de seus recursos naturais e mantendo, em parte, características tradicionais no convívio com o meio ambiente. ${ }^{18}$ Além de manguezais, a APA-Guapimirim compreende igualmente regiões ocupadas por atividades agrícolas ligadas a pequenos núcleos habitacionais, com baixa densidade populacional. Vale ressaltar que as áreas urbanas do entorno da APA são de municípios com grande carência de 
saneamento básico e fornecimento de água, tendo uma taxa de domicílios atendidos por coleta de lixo variando de $60 \%$ em Itaboraí, a 91\% em São Gonçalo.

O cenário que envolve a Apa também não é muito animador. Como já dissemos, na Baía de Guanabara concentra-se um parque industrial com cerca de 14 mil indústrias e, diariamente, a baía recebe 465 toneladas de esgoto doméstico, sendo que apenas 68 toneladas são tratados. Cerca de mil toneladas de lixo produzidos na Bacia da Baía de Guanabara vão para os rios, sendo que a oferta de água região nao é insuficiente para a demanda urbana e rural.

Segundo o Plano de Gestão da APA Guapimirim, o desenvolvimento de um conjunto de elementos poderia levar a um processo profícuo de conservação ambiental. Dentre estes são destacados os seguintes: a) o grande potencial de que os manguezais dispõem para a reprodução da diversidade biológica; b) o sustento que seus recursos naturais proporcionam à população local; c) o potencial turístico oferecido pelos manguezais preservados e pelos seus monumentos arqueológicos (sambaquis); d) a proximidade da Apa com as grandes Universidades (UFRJ, UERJ, UFF) capaz de atrair o interesse da comunidade científica; e) os conhecimentos oriundos da população que habita a APA e importância dos mesmos para uma relação harmoniosa do homem com o seu meio ambiente.

Diante de diversos riscos ambientais que a Apa de Guapimirim sofre, e pela percepção da diminuição dos recursos pesqueiros, no inicio de 2006, o Ibama propôs a criação de uma Estação Ecológica abrangendo 2 mil hectares da porção mais preservada de toda a APA e de toda a Baía. O Ibama argumentava que a criação de uma unidade de conservação de uso restrito permitiria a regeneração dos recursos naturais e, por conseqüência, geraria um aumento da fauna marítima no entorno, garantindo assim a sustentabilidade das atividades tradicionais. Apesar de não ter tido um consenso geral das comunidades interessadas, sobretudo dos pescadores e dos caranguejeiros, a Estação Ecológica da Guanabara foi instituída. Entre os argumentos que justificavam a decisão do Ibama, ressaltava-se o caráter desta área como sendo o último remanescente de manguezal primário da Baía de Guanabara e como sendo de fácil proteção por guardar uma relativa distância das pressões urbanas.

No plano físico, a área prevista para a instalação do Comperj é muito próxima das unidades de conservação. Isto fez com que os respectivos Conselhos Gestores tenham expressado o temor para uma serie de impactos de nature- za diversa e que agirão de forma cumulativa, ampliando seus efeitos negativos sobre as unidades de conservação e a região em geral. A previsão das emissões aéreas do complexo apontam para um raio de influencia direta de 20 quilômetros, o que as levariam a atingir não só as unidades mais próximas, mas, pela ação dos ventos, também as mais afastadas. Em particular, a área de transição entre o futuro Comperj e a Apa de Guapimirím é muito reduzida. Atualmente esta área que é dedicada à agricultura e têm baixa densidade demográfica, mas poderá ver os assentamentos humanos intensificar-se significativamente, atraídos pela construção do anel rodoviário e das novas indústrias.

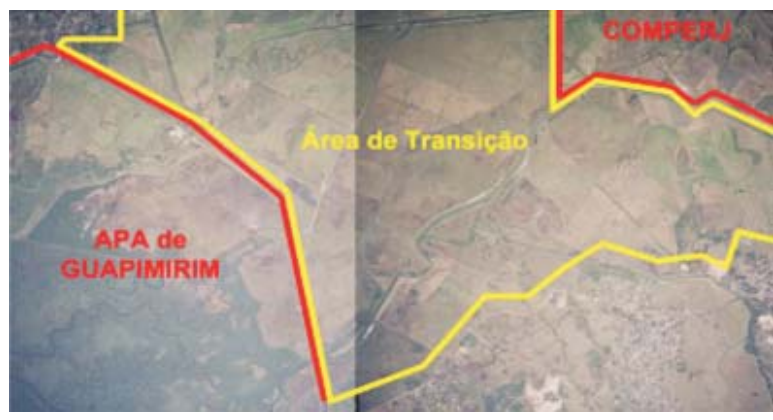

MAPA EXTRAÍDO DAAPRESENTAÇÃO DE SOARES (2007)

A preocupação com o crescimento urbano desordenado em uma região em que os municípios têm tradicionalmente gravíssimos problemas com abastecimento de água, com crescimento de favelas e com falta de saneamento básico, também se justifica face à previsão de que o Comperj e as indústrias anexas poderão atrair para região consideráveis contingentes de população em busca de trabalho. Na região há um prognóstico de déficit de água, devido à grande demanda para abastecimento tanto das residências dos 2,5 milhões de habitantes dos municípios de Cachoeiras de Macacu, Itaboraí, Guapimirim, São Gonçalo e Niterói, como dos animais das áreas rurais. O analista do IBAMA, Alfredo Barros (2007), já havia expresso suas preocupações quanto à falta de planejamento integrado em relação ao fornecimento de água e destinação dos efluentes. Entretanto, os sistemas de fornecimento de água e destinação dos efluentes irão ter processos de licenciamento ambiental separados. A FEEMA concedeu a licença previa mesmo sem uma definição de onde o Comperj irá se abastecer da água que necessita, nem de onde os efluentes líquidos serão despejados. A este respeito, cabe ressaltar que, não somente todos os licenciamentos 
necessário para os sucessivos novos empreendimentos que venham a instalar-se na região, serão avaliados singularmente, mas as próprias atividades do Comperj serão licenciada individualmente, já que o processo de licenciamento ambiental do projeto foi fracionado em 50 partes e cada atividade terá uma licença própria.

Considerando a escassez de água nesta região e a fragilidade do ecossistema da Baía de Guanabara, causa muita preocupação também a própria construção física do Comperj, somada às construções de todas as outras indústrias que poderão vir e dos assentamentos humanos que poderão atrair. Prevê-se que estas intervenções comprometerão de forma significativa o futuro estado das bacias de drenagem da região. ${ }^{19}$ Como mostra a figura abaixo, a pavimentação de vastas áreas da região, hoje aluvionais, ameaça seriamente a capacidade das bacias de drenagem de recolher água suficiente para abastecer os rios da região.

A localização do Comperj, com sua forte demanda

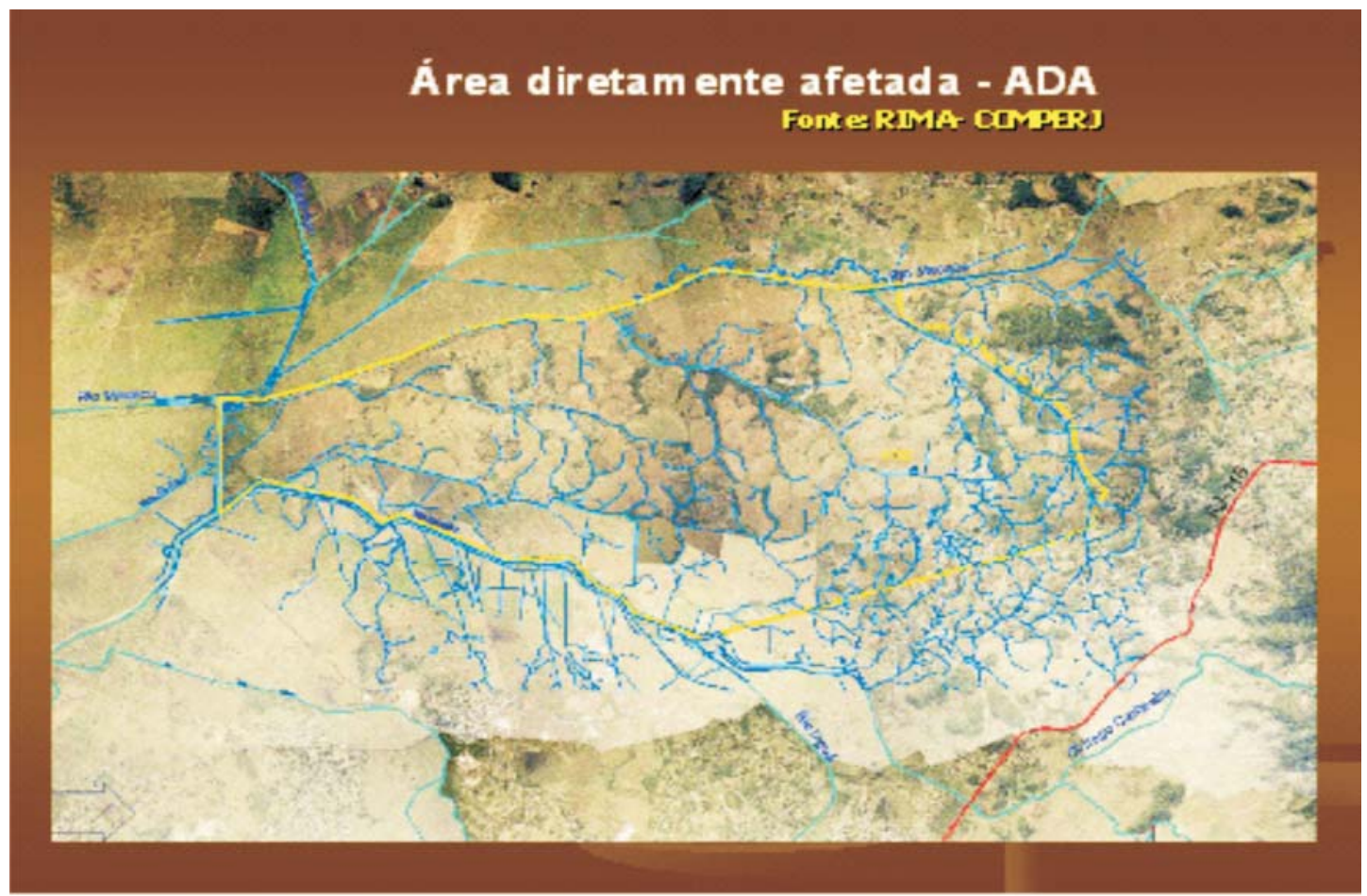

NOTA: A linha interna em amarelo indica a área da planta do Comperj e as linhas em azul os percursos de drenagem.

FONTE: Rima-Comperj

por água numa região que sofre com problemas de abastecimento, além da possibilidade de contaminação da água por resíduos industriais, estaria contrariando o próprio Plano Diretor de Recursos Hídricos da Região Hidrográfica da
Baia da Guanabara (PDRH-BG).$^{20}$ Segundo o PDRH-BG, a Área Leste da Baia abriga importantes UCs (ou parte delas) do MMCF, como as APA's de Petrópolis e de Guapimirim, o Parque Nacional da Serra dos Órgãos, O

19 Uma Bacia de Drenagem, ou Bacia Hidrográfica de um curso de água, é o conjunto de terras que fazem a drenagem da água das chuvas, isto é, escoam as águas de terrenos encharcados, por meio de túneis, canais, valas e fossos, para os curso de água.

20 O PDRH-BG faz parte de uma série de ações do Programa de Despoluição da Baía de Guanabara - PDBG, cujo objetivo é melhorar a qualidade ambiental da Baía de Guanabara e de toda a região a sua volta. 
parque Estadual dos Três Picos e a Estação Ecológica (ESEC) do Paraíso. O PDRH-BG, prevê para essa área ações como a consolidação da vocação regional para abastecimento local e a possível exportação da água para outras regiões fora da RHBG, além da conservação dos ecossistemas locais e litorâneos. O Plano recomenda que as áreas inundáveis ainda não ocupadas não sejam urbanizadas e que os respectivos municípios criem uma legislação que as torne não urbanizáveis. ${ }^{21}$

Soares (2007) aponta para uma serie de paradoxais contradições. Tanto a própria Petrobrás teria reconhecido que a área próxima ao Comperj estará sujeita à ocupação desordenada, como o Diretor de Inclusão Social do BNDES teria declarado, que boa parte dos mais de 200 mil trabalhadores envolvidos na fase de construção do Comperj permanecerão em favelas na região após a conclusão do mesmo. Contraditórias aos fatos seriam também, de um lado, a avaliação do Ministério do Meio Ambiente quando classifica a Baía de Guanabara como área de alta importância biológica, ${ }^{22}$ de outro, o Programa de Despoluição da Baía de Guanabara que se baseia na redução das descargas de esgotos domésticos e industriais para a baía. A conclusão do oceanógrafo da UERJ é que a localização proposta para instalação do Comperj, não somente fere princípios básicos do PDRH-BG, mas fere também princípios básicos do Gerenciamento Costeiro pregados pelas Políticas Nacionais de Gerenciamento Costeiro e de Recursos Hídricos.

Não menos importante é o risco de acidentes. É pesado o histórico de acidentes ambientais ocorridos na Baía de Guanabara e, entre os maisgraves, está o vazamento de 1,3 milhões de litros de óleo da Petrobrás ocorrido em 2000. Neste período houve uma expressiva redução de peixes na baía, o que acarretou grandes dificuldades para as comunidades pesqueiras. Segundo o ambientalista Sérgio Ricardo, estima-se em mais de R $\$ 1$ bilhão o valor a ser pago aos pescadores, sendo a maior indenização por dano ambiental já vista no país. O mai recente, ocorrido em abril de 2005 em Porto das Caxias, distrito de Itaboraí, foi o descarrilamento de cinco vagões da Ferrovia Centro-Atlântica (FCA), que transportavam óleo diesel da empresa de petróleo Ipiranga, em Duque de Caxias, para Campos, na Região Norte Fluminense. O acidente provocou o derramamento de mais de 60 mil litros deste produto no rio Caceribú, atingindo cerca de 12 quilômetros do rio. O óleo se espalhou por dentro dos manguezais da Apa de Guapimirím, até atingir a Baía da Guanabara, contaminando caranguejos e peixes, o que levou o Ibama proibir a pesca até o início de maio daquele ano.

Por ultimo, podemos nos interrogar sobre o que acontecerá à população que vive da pesca e da captura de caranguejos na Apa de Guapimirím. Na primeira das duas imagens que seguem, nos contornos amarelos, está representada a parte da localidade de Itambí (município de Itaboraí) onde atualmente se concentram as moradias da maioria desta população. Esta área, em parte destinada a servir às obras do Arco Rodoviário do Rio de Janeiro, deverá ser liberada e a sua população deverá ser reassentada na parte indicada pelo contorno verde. Na segunda imagem, estão representadas as novas habitações destinadas à mesma população. Em primeiro lugar, são blocos de apartamentos que irão substituir as casas em que moram atualmente; em segundo lugar, as novas habitações são situadas numa área bem mais afastada dos mangues e dos rios, ficando também separadas destes pela Rodovia BR-493 RJ, destinada a ser um segmento do Arco Rodoviário. Rápidas pesquisas feitas por técnicos do IBAMA estariam apontando para certo consentimento por parte da população prevista para ser reassentada. Entretanto cabe perguntar se as atividades de pesca e de captura poderão ser mantidas nas novas condições ou se a população terá que buscar novas formas de vida (MOYSES DOS SANTOS, 2008). Neste segundo caso, a Apa de Guapimirím poderia perder um potencial de conservação muito importante, já que a extinção das atividades ditas "tradicionais" eliminaria também a presença na área de potenciais vigias da conservação (GIULIANI et al., 2005). 


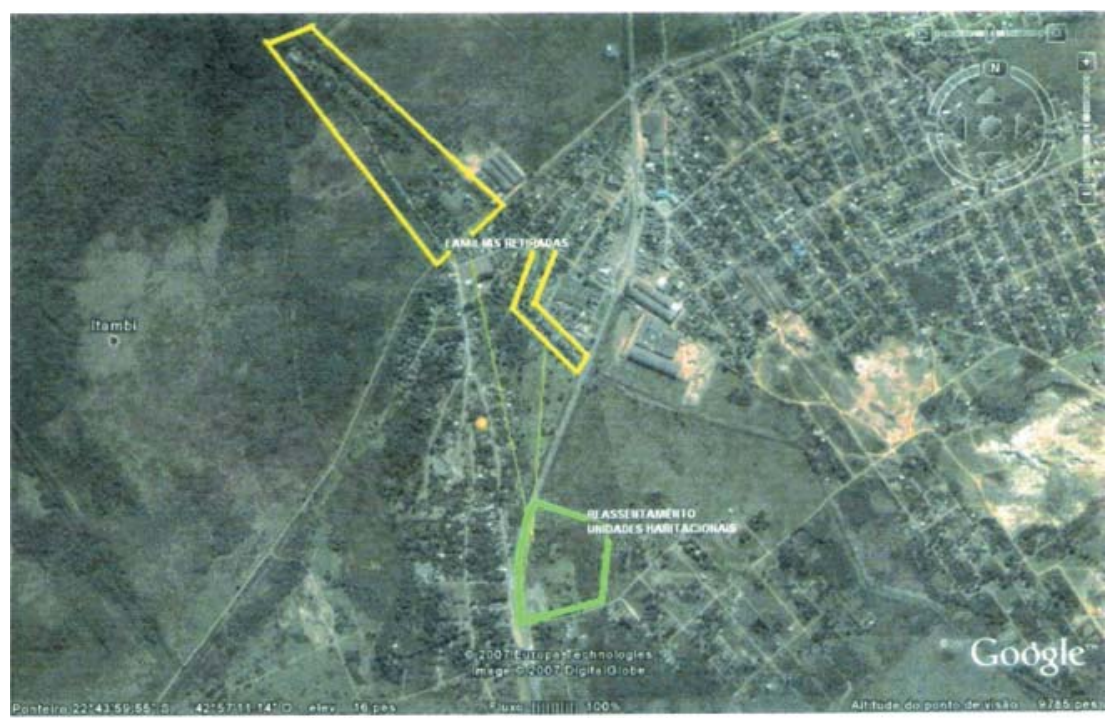

- Local de onde as familias serão retiradas (Bacia);

- Canal scrá revitalizado;

- Um ETE será construído;

- Local do reassentamento dos moradores da "Bacia":

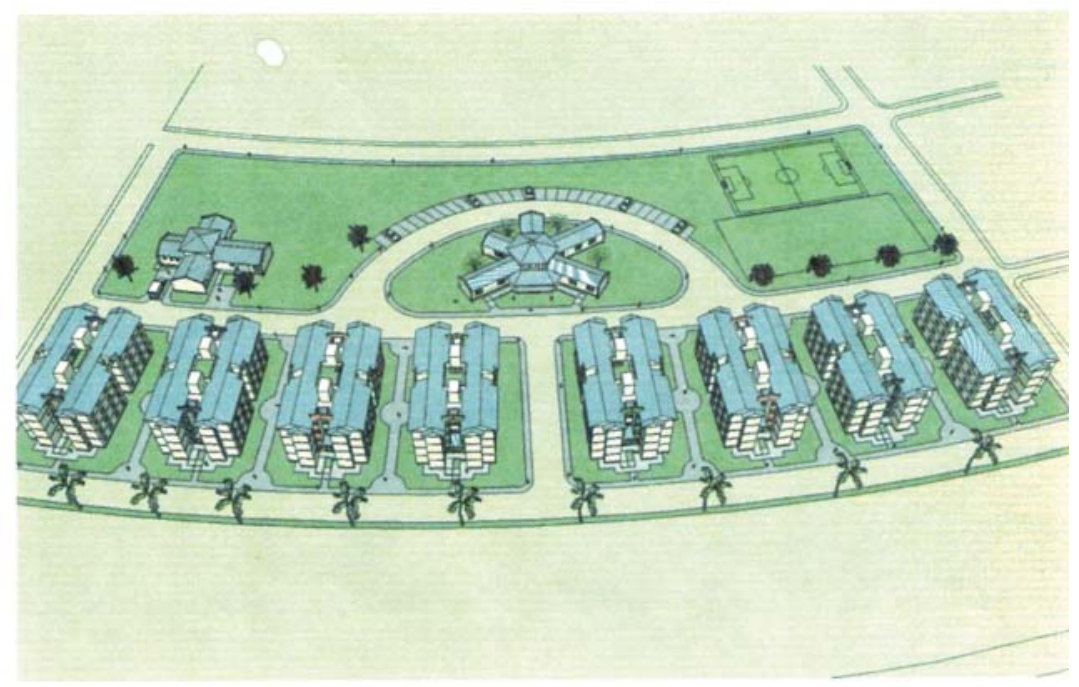

- Maquete de conj. Hab. Nov Itambi, onde serão realocados os moradores da "Bacia"- Itambi:

FONTE: Parecer Técnico 53/207 Apa-Guapimirim, 13 de dezembro de 2007. 


\section{Conclusões}

Os custos sociais da despoluição podem ser bem mais altos que os custos da precaução e da prevenção, mas será que este balanço vale para as empresas? É compreensível que uma empresa se senta responsável principalmente por produzir e lucrar, criando riqueza, desenvolvendo tecnologia e crescendo. Entretanto o lema da RSAE expressa a necessidade de fixar princípios e também limites para os processos de crescimento que, ao considerar o caso especifico do projeto do Comperj, suscitam uma serie de questões.

A primeira se refere a "quando" deveria se fazer presente a responsabilidade. Antes, durante ou depois da ação? Parece que tanto a social como a ambiental se referem às fases operativas da empresa. Por exemplo, no âmbito da responsabilidade social relativa ao processo de expropriação da área de sua instalação, a empresa promete reassentar os 175 proprietários, os 122 veranistas e os 53 residentes, empenhando-se também a ocupar os 301 empregados rurais no plantio de 4 milhões de mudas no projeto do Corredor Ecológico ao redor das instalações do Comperj. Entretanto, a expropriação é efetuada independentemente da vontade dos proprietários e habitantes, já que os que não aceitarem as propostas da empresa serão expropriados por utilidade pública e ressarcidos com valores baseados no Imposto Territorial Rural (ITR) pago. Por outro lado, as respostas a serem dadas aos processos de urbanização desordenada que ocorrerão, são delegadas aos órgãos públicos e às organizações locais da sociedade civil. Assim, a responsabilidade da empresa não é preventiva, no sentido de planejar as intervenções, prever os problemas e organizar o projeto no sentido de evitá-los. A responsabilidade social se funda em atitudes, no máximo, de compensação ou de reparação pelos problemas causados.

Uma segunda questão se refere à natureza da responsabilidade, em particular no campo ambiental. Face aos riscos, amplamente comprovados, aos quais as Unidades de Conservação serão expostas com as atividades do Comperj e a ampliação do parque industrial nas suas proximidades, as intervenções propostas pela empresa visam somente atenuar os desequilíbrios ambientais já previstos antes da própria ação. Nesse sentido, a lógica da empresa, ignora o principio de precaução e age de forma pontual e não sistêmica.
Em quanto ignora a complexidade ecossistêmica da região e suas diversas formas de integração sociedade-natureza, esconde os efeitos cumulativos e combinados de todas as ações industriais na região. Tais efeitos poderão ser negativos para a conservação das áreas protegidas e a biodiversidade, mas serão negativos também para a cultura e as formas de organização social das populações que não estão estritamente integradas na lógica capitalista e na perspectiva do crescimento econômico. Neste caso parece haver um verdadeiro confronto entre a lógica da conservação, tanto da biodiversidade como da sociodiversidade, face à lógica do crescimento econômico.

Nos perguntamos se esta contraposição poderia ser aliviada através do fortalecimento das instâncias democráticas de participação nos Conselhos Gestores das UCs, no sentido de usar os meios institucionais mais apropriados para que a conservação possa ser sustentada com eficácia. Lamentavelmente, as perversas condições socioeconômicas da sociedade brasileira colocam um paradoxo no plano da relação entre a democracia e a conservação. De um lado, as populações pobres residentes nas UCs e no seu entorno não chegam a alcançar um grau de organização bastante forte para que seus interesses sejam tomados em consideração. Sendo assim, são levadas a aplaudir qualquer intervenção na região que traga promessas de crescimento econômico, mesmo à custa de graves perdas no plano ambiental e social.

Além disso, os próprios Conselhos Gestores das UCs enfrentam contradições difíceis de serem superadas. Mesmo desaprovando a intervenção que poderá afetar negativamente a conservação das áreas naturais, não têm poder para influir sobre as decisões da grande empresa em um projeto que se insere no Programa de Aceleração do Crescimento promovido pelo Governo Federal. As grandes empresas, mesmo as que proclamam insistentemente que "tudo o que fazem o fazem com responsabilidade social e ambiental” (slogan da Petrobras), têm um poder preponderante no território e seus interesses são impostos como sendo o melhor para a sociedade inteira. O geógrafo Milton Santos já alertava:

A presença das empresas globais no território é um fator de desorganização, de desagregação, já que elas impõem cegamente uma multidão de nexos que são do interesse próprio, nexos que refletem as suas necessidades individualistas, particularistas ${ }^{23}$ 
A construção do Comperj em um território que inclui as unidades de conservação produzirá transformações profundas no sentido contrário à política ambiental que há mais de duas décadas se busca implementar na região que liga a Serra da Mantiqueira à Baia da Guanabara, na tentativa de conservar e expandir o reduto maior do $7 \%$ que resta da Mata Atlântica. O efetivo poder no território parece estar afora e distante da capacidade de gestão dos atores que nele vivem e de sua capacidade de implantar políticas econômicas e tecnológicas com incidência estratégica, capazes de desenvolver as potencialidades endógenas. A gestão é exercida pelo Estado e seus múltiplos e hierarquizados atores, sendo que a abertura à participação da sociedade civil e da população diretamente envolvida resulta mais formal de que real. Com efeito, os processos de expropriação das terras são cumpridos “por utilidade pública”, os licenciamentos são baseados em Relatórios de Impacto Ambiental fragmentados e parciais de modo que impedem qualquer conhecimento dos possíveis efeitos cumulativos e combinados das atividades propostas. Assim, as audiências públicas servem praticamente para comunicar as decisões.

Ainda prevalece no mundo dos empresários e dos operadores econômicos a concepção da natureza como objeto de conquista e exploração, base de uma visão hostil aos limites ecológicos que obstaculizam o crescimento econômico, que inibem o progresso e freiam a liberdade. $\mathrm{O}$ próprio Rose o reconhece ao afirmar que:

Para a maioria dos agentes de governos e dos empresários, a questão ambiental permanece secundaria, pois requer alocação de recursos que - sob uma ótica de curto prazo - não trazem retorno significativo, tanto nas urnas quanto nos caixas. ${ }^{24}$
Neste ambiente cultural, as empresas que querem ser ambientalmente "responsáveis” acabam produzindo discursos e práticas visivelmente incongruentes.

O meio ambiente não é a preocupação principal da burocracia estatal. Não há estado que tenha planos ambientais globais, isto é, integrados nos eventuais programas de crescimento econômico. No plano ambiental, o que o Estado desenvolve são somente propostas de contenção de danos previstos (através dos obrigatórios estudos de impacto ambiental) e soluções de remendo aos danos feitos, mais freqüentes, através dos termos de ajustamento de conduta, mais raramente, através das condenações por crimes ambientais e, obrigatoriamente, pelas compensações previstas por lei.

Pelo lado empresarial, a lógica da Responsabilidade Ambiental é impregnada por um desmedido entusiasmo pelo desenvolvimento tecnológico, do qual, em teoria, deveriam surgir instrumentos para a conservação da natureza. Porém, no estado atual, o avanço tecnologico produz meios sempre mais poderosos e eficientes para "refazer" a natureza, desconsiderando os custos decorrentes da perda dos serviços que esta fornece gratuitamente e a aflição decorrente da degradação da qualidade de vida. Mais parece que a sociedade capitalista pouco se preocupa com a perda dos serviços gratuito da natureza (geração e conservação da água, do ar e solo sadios), pensando que poderá substituí-los com serviços proporcionados pelo capital, abrindo, assim o propalado "setor ambiental como novo campo de investimentos lucrativos”. De fato, o chamado discurso verde das empresas põe ênfase somente no que se refere aos processos produtivos, isto é, na tecnologia, na reciclagem, na eficiência energética e na proteção de áreas naturais consideradas como meras reservas de biodiversidade para projetos industriais futuros. 


\section{Referências}

ACSELRAD, Henri; HERCULANO, Selene; PÁDUA, J.Augusto. Justiça Ambiental e Cidadania. Rio de Janeiro: Relume Dumara, 2004.

ACSELRAD, Henri; LEROY, Jean Pierre. Mapa dos conflitos ambientais no Estado do Rio de Janeiro - 1992-2002. Rio de Janeiro: IPPUR-UFRJ e FASE (divulgação digital).

ALMEIDA, Fernando. Desenvolvimento sustentável e novas oportunidades de negócios. In: FELDMAN, F. (Ed.). Rio + 10 Brasil. Uma década de transformaçõe, Rio de Janeiro: MMA, ISER, FBMC, 2002.

AMADOR, Elmo. Disponível em: <http:// www.ecopress.org.br>. Acesso em: 23/2/2007.

ANDERSON, C. Corrente de solidariedade mobiliza brasileiros. O Globo, 25 jun. 2000.

ANDERSON, T. L.; LEAL, T. R. Ecologia de livre mercado. Rio de Janeiro: Expressão e Cultura, 1992.

BOLTANSKI, Luc; CHIAPPELO, Eve. Le nouvel Esprit du Capitalisme. Paris: Gallimard, 1999.

BODET, Catherine; LAMARCHE, Thomas. La RSE comme innovation institutionnelle: une lecture régulationniste, 2007. Disponível em: <http://regulation.revues.org/ document1283.html>.

CAPPELLIN, Paola; GIULIANI, Gian Mario. The political economy of corporate responsibility in Braizil: social and evironmental dimensions. Technology, Business and Society, Paper n. 14, ISSN 1020-8216, United Nations Research Institute for Social Development- UNRISD, Genève, Otubro 2004.

CORREA LIMA, J. Paladino; FERNANDES DOS SANTOS, L. Antonio. Uma proposta de planejamento e gesta ambiental: justificativa. Revista Floresta e Ambiente, v. 5, n. 1, p. 216218, jan./dez. 1998. Disponível em: <http://209.85.215.104/ search?q=cache:Poya6TtnLh8J:br.geocities.com/floramrural/ 0216.pdf+Floresta + Nacional + M\%C3\%A1rio+Xavier\&hl= it\&ct $=$ clnk\&cd $=1 \& g l=i t>$.

GALLINO, Luciano. L'Impresa irresponsabile. Torino: Gli Struzzi Einaudi, 2005.

GIULIANI, G. M.; GONCALVES, S. D.; GIFFONI, P. R.; GUEDES, M.; MONNERAT, B. S.; CASTRO, R.; OLIVEIRA, R. R.; MONTENEGRO, T. Diagnóstico socioeconômico da população residente na localidade de ITAMBÍ, município de Itaboraí (RJ). Relatório, IFCS-UFRJ, 2005.
HAWKEN, P.; LOVINS, A.; LOVINS, L. H. Capitalismo natural: criando a próxima revolução industrial. São Paulo: Cultrix, 1999.

KINLAW, D. C. Empresa competitiva e ecológica (Competitve \& Green, 1993). São Paulo: Makron Books, 1997.

LANDIM, L. (Ed.). Ações em sociedade: militância, caridade, assistência etc. Rio de Janeiro: ISER/ NAU, 1998.

LANDIM, L.; SCALON, M.C. Doações e trabalho voluntário no Brasil. Rio de Janeiro: 7 Letras, 2000.

MARINHO, Janot N. Entendamos a filantropia. Bem Comum, São Paulo, FIDES, n. 79, 2003.

MOYSES DOS SANTOS, Yana. A importância da articulação dos conhecimentos científicos e tradicionais para a conservação dos manguezais da Apa de Guapimirím. Monografia (Final do Curso de Oceanografia) - Instituto de Geociências da Universidade Estadual do Rio de Janeiro - UERJ, 2008.

NOGUEIRA, Ítalo; TORRES, Sergio. Carlos Minc licenciou obras em tempo recorde no Rio. Folha de S.Paulo, 15/5/2008. Disponível em: <http://www1.folha.uol.com.br/folha/brasil/ ult96u402074.shtml>.

PAES FERREIRA, M. Ines et al. (CEFET-UENF). Desafios à gestao ambiental para a área de influência do Comperj, Itaboraí, RJ. XXVII ENEGEP, Foz de Iguaçu, 2007.

RIMA-COMPERJ Petrobras-Concremat Engenharia. Disponível em: <http://www2.petrobras.com.br/ Petrobras/ portugues/pdf/rima.pdf $>$.

ROSE, Ricardo. Meio ambiente urbano: há muito por fazer. Disponível em: <http://www.responsabilidadesocial.com/ article/article_view.php?id=586>. Acesso em: 22/5/2008.

SOARES GOMES, Mario L. Responsabilidade socioambiental: a difícil transposição do "abismo"que separa a retórica da prática. Considerações sobre a proposta de localização do Comperj. Apresentação ao Conselho do Mosaico da Mata Atlântica Central Fluminense, II Reunião Ordinária, 01 out. 2007.

WAMBIER, Ana. Baía tem 15 empresas com alto risco de acidentes. O Globo, 22 set. 2004. Disponível em: <http:// www.ambientebrasil.com.br/composer.php3?base=./snuc/ index.html\&conteudo=./snuc/sudeste/fn/xavier.html >; < http:// www.ibama.gov.br/resex/pop.htm>; < http://www.cibg.rj.gov.br/ detalhenoticias.asp? codnot $=363 \&$ codman $=22>$. 